ates, Inc., and will have the following persons as editorial advisors: Louis Shores, Florida State University; Dan Sillers, president of Jamestown College, N. Dakota; Robert Jordan, Council on Library Resources; W. Stafford North, dean of instruction at Oklahoma Christian College; Thomas Minder, director of Pittsburgh Regional Library Center; Sister Helen Sheehan, librarian and trustee at Trinity College of Washington, D.C.; and Howard Clayton, librarian at State University of New York, Brockport, N.Y. Subscription rates for the new journal will be $\$ 8.00$ per year. Further information concerning The Library-College Journal may be obtained from Howard Clayton, Box 173, Brockport, N.Y., or from any of the editorial advisors.

\section{HERBERT ANSTAETT CITED}

Herbert B. Anstaet librarian emeritus and bibliographer of Franklin and Marshall College, Lancaster, Pa., was awarded the honorary degree of Doctor of Humane Letters, at the Opening Convocation of the 1967-1968 academic year at the college on September 14. Professor Anstaett recently retired from the position of librarian, which he had held since 1927.

The Honorable John W. Gardner, Secretary of Health, Education and Welfare, received the degree of Doctor of Laws at the Franklin and Marshall Convocation.

The citation of Professor Anstaett read as follows:

Herbert Bulow Anstaett-A nineteenth century poet, Silas Weir Mitchell, once turned a phrase that speaks volumes about Herbert Anstaett, Bookman to Franklin and Marshall College since 1927. "Show me the books he loves," Silas Mitchell wrote, "and I shall know the man far better than through mortal friends."

To begin knowing Professor Anstaett, one must look first to 194,000 books which he truly loves; the books at Fackenthal library, more than 150,000 of which have been acquired during his forty years' romance there. And, in a very real sense, the books he loves extend far beyond the Fackenthal collection, to include the numerous additional volumes which he successfully cataloged as one of the first editors of Books In Print.

The books he has known concur eloquently with mortal friends by the score who speak of the humane depth of his understanding, the breadth of his scholarly interests, and the excitement of a voyage toward even the most remote bibliographic poet in his wake.

The scope and richness of his career have brought him recognition as one of the nation's outstanding college librarians. But we would rather know him as a prime example of the genius inherent in liberal arts education when it is conducted on a very personal scale. For he has made wisdom gained through major professional accomplishment available on an individual basis to all who use Fackenthal library, thus serving as a catalyst in that subtle chemistry, that stirring intellectual ferment which

\section{MALC IN 1968}

The Midwest Academic Librarians Conference will be held in Winona, Minnesota, May 3-4, 1968. The host colleges will be: Winona State College, College of St. Teresa, and St. Mary's College.

sometimes makes this campus seem an English coffee house raised to the $n$th power.

While quadrupling the Fackenthal library collection; editing the monumental Books In Print and coediting its related Subiect Guide to Books In Print; serving as president of the Pennsylvania Library Association; and crusading effectively for improved public library service throughout the Commonwealth; he has always remained an enthusiastic guide and partner in an amazing variety of scholarly endeavors. A big library, he would tell you, is only as good as its handling of the smallest demand for its services. Thus, he has made Fackenthal library a place where a professor's call about a reference from the Vatican library and a student's need for pictures of the instruments in an orchestra both receive overabundant at tention; a place where your need for a single volume and the librarian's preoccupation with an entire collection never come into conflict.

\section{OTTO HARRASSOWITZ Library Agency WIESBADEN • GERMANY}

\author{
Direct service \\ on all German language \\ books and periodicals
}

Orders and inquiries are invited on both new and out-of-print material

Farmington Plan agent for West and East Germany

For economy, speed, and accuracy you may rely upon your

German agent OTTO HARRASSOWITZ 